who has a laced waistcoat is too fine a man to work ; but if everybody had laced waistcoats, we should have people working in laced waistcoats."

Lastly, the ironical may ask whether it is an error to suppose that the education of the people should furnish them with useful knowledge and abilities. Now the test of utility which the plain man applies to education is, in principle, sound and indispensable : the only point doubtful is whether the test is always based upon a sufficiently broad idea of utility. The only satisfactory definition of the useful is that it contributes definitely and positively to fullness of life. From that point of view it is useful to teach a ploughboy to love poetry and not useful to teach a public schoolboy to hate Greek. This is not an argument against teaching a subject the disappearance of which from our education would be an irreparable disaster. It means merely that the literatures of the ancient world, when taught, should be taught in such a way as to contribute positively to the quality of a modern life. But the term "useful," according to the definition, certainly includes utility in the narrower sense. The daily work of the world must be kept going, and one of the essential tasks of the schools is to fit the young to carry it on under the immensely complicated conditions of present-day civilisation. The only limitation imposed by our argument is that what is conservative in purpose shall be creative in its method and, being so, shall embody some dignified tradition of practical, æsthetic, or intellectual activity. The condition may be satisfied by a technical education based upon many of the great historic occupations of men and women, provided that inspiration is sought from the traditions of the industry or craft at their noblest. To conceive "secondary education for all" as meaning "the grammar school curriculum for all " would be to make a most serious blunder. The only mistake more serious would be to exclude adolescent boys and girls, even of the humblest station, from any essential part of the national inheritance of culture. But this error may be avoided while full account is yet taken of the far-reaching differences in the talents and ingenium of individuals and the rich diversity of the valuable currents, intellectual, practical, and æsthetic, in the life of the community, of which any one may be made the basis of a course truly liberal in quality.

The last hundred years have greatly accentuated the gravity of a problem which was discerned by the poet Schiller and diagnosed in the famous "Letters on Æsthetic Education" he published in I795. In Schiller's view the immense progress of the modern nations has been purchased at the expense of the development of the individual soul, so that, in spite of the greatness of our achievements, we are, man for man, inferior to the various and well-rounded Athenians of the best days. It is the division of labour essential to a large-scale organisation of society which has at once made general progress possible and individual impoverishment inevitable, for it has cut individual men off from experiences that are indispensable to the full well-being of mankind. If this was true in the days of the French Revolution, how much more true it is to-day, and how much more grave the evil. We are told that before the era of industrialism the great mass of our people enjoyed a culture which, though simple, was sincere and at least kept them in touch with the springs of beauty. What truth there is in the picture I do not know, but it is certain that with what is called the industrial revolution the conditions that make it credible largely disappeared. Torn from the traditions of the old rural life and domestic industry and herded into towns where in the fight for mere existence they lost their hold on all that gave grace to the former life, the folk who now constitute the bulk of our population were cut off effectually from "sweetness and light." That was the situation when the task of public education was taken seriously in hand, and that, notwithstanding a great amelioration in details, is for far too many the situation to-day.

There are some who think that the only remedy is to cry halt to the modern movement and return deliberately to medievalism. That is a counsel of despair ; instead of indulging idle dreams it will be more profitable, assuming the unalterable conditions of modern life, to consider how the rest may so be modified as to place the true dignity and grace of life within the reach of all who are qualified to achieve them. That can be done only by a system of education which brings the things of enduring and universal worth to the doors of the common people. It is what has been done by many an elementary school teacher, sometimes with scant assistance from public opinion, simply because, face to face with his helpless charges, he was impelled to give them the best he had to give. It will be done with increasing happy results the more clearly it is seen that the proper function of the elementary schools is something much more than to protect the State against the obvious danger of a grossly ignorant populace or to "educate our masters " in the rudiments of citizenship. Unless it be done, unless the natural hunger of the people for knowledge and beauty be wisely stimulated and widely satisfied, no material prosperity can in the end save the social body from irretrievable degradation and disaster.

\title{
New Discoveries and Paintings of Palæolithic Date in the Department of the Lot (France).
}

TH E study of palæolithic man is many-sided. As a geologist, treating the tools and objects manufactured by prehistoric man as fossils, the prehistorian has determined an archæological sequence, and, by correlating this with the geological record of the earth's history, has been able to suggest a probable chronology. As an anatomist, the prehistorian has launched into the fascinating study of the evolution of man, and, although hampered by lack of authentic material, has already been able to show that this evolution was by no means a simple straightforward affair. As fresh material comes to hand it will become possible to elucidate further this complex branch of the subject. As an ethnologist, the prehistorian has attempted to trace the migrations of prehistoric races, and to compare their cultures with those of primitive folk still surviving. 
But perhaps the most entrancing branch of prehistory is the study of the mural art of these very early peoples. Here we are not dealing merely with "dry bones" or objects made for some immediate and concrete use, nor indeed are we dealing, in the vast majority of cases, with mere "home" decoration. Primitive man, then as now, was concerned with his food supply, and the art was practised as a form of sympathetic magic. The veil lifts for a moment, revealing to us the very thoughts and aspirations - one might almost say the religion - of these early artists. The occurrence of prehistoric ceremonial burials has further helped in this study, indicating, as it probably does, something of the nature of a cult of the dead. Perhaps some of the cave art may be connected with this.

The palæolithic art for magic purposes occurs emblazoning the walls of caves. The darkness and silence of these entrances to the bowels of the earth is eminently suited to the production in primitive man of a state of mind receptive to magic influences. There is actually evidence to suggest that a priestly artist caste guided and controlled these emotions. The painted and engraved caves may indeed be described as prehistoric temples.

For this art to be practised, it is clearly necessary that natural caves should occur in the district. Hitherto three main areas of distribution have been located, one in Dordogne (France), around the village of Les Eyzies on the banks of the river Vezère, a tributary of the Dordogne; another in the Pyrenees, especially in the department of Ariège; the third in Cantabria (North Spain), and extending as far west as Asturias. It would now appear that, thanks to the energy of the Abbé
Lemozi of Cabrerets near Cahors (Lot), a new region is in process of discovery. An announcement of this has appeared in L'Illustration of October I3, p. 354. The article, profusely illustrated, deals with the finds of the Abbé Lemozi. It does not pretend to be a scientific exposition written by an expert. On the other hand, an exceedingly interesting sketch is given of the archæological work done by the Abbé, which it is to be hoped he will publish himself in due course. Not only have a number of prehistoric " homes " been discovered under overhanging rocks, many of which have yielded rich industries in stone and bone, but a painted cave temple, worthy to be compared with those of the Dordogne, Pyrenees, and Cantabria, has also been explored.

Judging from the illustrations, the date of the art would seem to be in part Aurignacian, in part lower Magdalenian, but it is impossible to be precise on this point from the meagre account given. The animals and figures observed apparently include reindeer, horse, mammoth, bison, "negative" human hands, signs, etc. Obviously much further work is required before what promises to be a new and rich area is properly explored, but the Abbé is to be congratulated on what he has already done, and L'Illustration is to be highly commended for having brought forward his work in such an excellent way. A complete survey of the district around Cabrerets, with a scientific account of the diggings and of the cave art, will be eagerly awaited by all prehistorians. Some reproductions of the new prehistoric paintings appeared in the Illustrated London News of October 20.

M. C. B.

\section{An African Chalicothere.}

\section{By Dr. Chas. W. Andrews, F.R.S.}

A SMALL collection of fossils from the neighbourhood of Albert Nyanza has recently been sent for determination to the British Museum by Mr. E. J. Wayland, director of the Geological Survey of Uganda. The beds from which these remains were derived are of late Pliocene or, more probably, Pleistocene age, since they include teeth of Hippopotamus and Phacochœrus which do not seem to be distinguishable from those of recent forms : with these are bones of crocodiles, Chelonia, a large Siluroid fish, and fresh-water shells.

Accompanying these remains there are two or three fragments of much greater interest. The most important is a phalangeal bone of such peculiar form that it is at once seen to belong to a member of the Ancylopoda (Chalicotheroidea). These animals are very aberrant perissodactyl ungulates in which, instead of hoofs, great cleft claws are developed, and the consequent modification of the foot bones is such that even a single phalangeal bone is easily recognisable. These large cleft claws were known so long ago as Cuvier's time, and he regarded them as belonging to a giant Manis ("Pangolin gigantesque"). It was not until I888 that Filhol was able to prove that they actually belong to an ungulate. The group first appears in the Middle Eocene of North America, and in later times it spread over the northern hemisphere, remains being found in the Upper Miocene beds of Samos and Pikermi, and in India and China in deposits as late as the Pleistocene.

The finding of a Chalicothere in Central Africa is of especial interest because a species occurs in Samos associated with Samotherium, which is very closely similar to the Okapi, the discovery of which a few years ago attracted so much attention. It seems just possible that a Chalicothere may still survive in the same region and may be the basis of the persistent rumours of the existence of a large bear- or hyænalike animal. For example, in a letter to Mr. M. A. C. Hinton from Capt. C. R. S. Pitman, of Kenya Colony, the writer inquires if anything is known of the "Nandi Bear," stories of which are constantly cropping up. Whatever it may turn out to be, the beast seems to be nocturnal in its habits and to resemble a very large hyæna, an animal in which the proportions of the fore and hind limbs are much as in some Chalicotheres.

It is to be hoped that great efforts will be made to settle what this creature is, since, if the suggestion made above turns out to be correct, it will be a discovery of far greater interest than the Okapi. It does not seem at all improbable that, in such a country, even a large nocturnal animal might escape notice for a long time : even in England few people have ever seen a badger in the wild state. 